\title{
Workplace Whistleblower Protection in Poland: Current Situation and Perspectives
}

\author{
Dagmara Skupień ${ }^{1}$ \\ https://doi.org/10.18778/8220-639-5.08
}

\section{Legal sources of general application}

Disclosures of breaches of law have a long tradition in the Polish history and date back to the times of monarchy. ${ }^{2}$ Disclosures reinforcing the rule of law were approved of by the rulers and rewarded financially. ${ }^{3}$ The positive approach to whistleblowers during the era of independence of Poland was undermined during the period of occupation, namely during the 19th-century partitions of the country, the Second World War and afterwards during the communist times. ${ }^{4}$ The times of unwanted foreign rule left the reticence for collaborators or denunciators, which did not disappear completely after the return to democracy in $1989 .{ }^{5}$ On the other hand, the reinforcement of the rule of law and fulfilment of international obligations after the political transformation led to the creation of different institutions and measures

1 Dr hab. Dagmara Skupień, Professor at the University of Lodz.

2 See more about the history of whistleblowing in Poland: M. Ożóg, Sygnalizacja naruszeń prawa a zasada praworzqdności w dziejach prawa polskiego - zarys problematyki (Disclosures of breaches of law and the principle of rule of law in the history of Polish law - the outline of problems), [in:] B. Baran, M. Ożóg (eds.), Ochrona sygnalistów. Regulacje dotyczqce osób zgłaszających nieprawidłowości (Protection of whistleblowers. Rules concerning persons disclosing irregularities), Wolters Kluwer, Warsaw 2021, pp. 241-257.

3 See M. Ożóg, Sygnalizacja naruszeń prawa..., op. cit., p. 247.

4 See $Ł$. Bolesta, In Search of a Model for the Legal Protection of a Whistleblower in the Workplace in Poland, Peter Lang, Berlin 2020, pp. 94-95 or A. Savage, Whistleblowers for change. The social and economic costs and benefits of leaking and whistleblowing, Open Society Foundations 2018, p. 12.

5 Compare T. Kocurek, Działalność sygnalistów jako przejaw społeczeństwa obywatelskiego w szerszym kontekście historycznoprawnym (Whistleblower activity as a manifestation of civil society in a broader historical and legal context), [in:] B. Baran, M. Ożóg (eds.), Ochrona sygnalistów. Regulacje dotyczące osób zgłaszających nieprawidłowości (Protection of whistleblowers. Rules concerning persons disclosing irregularities), Wolters Kluwer, Warsaw 2021 pp. 263-264, or H. Szewczyk, Whistleblowing. Zgłaszanie nieprawidłowości w stosunkach zatrudnienia (Whistleblowing. Disclosing irregularities in employment relations), Scholar, Warsaw 2020, p. 44. 
supporting disclosures of irregularities and providing whistleblowers with protection against retaliations.

The rules for the protection of workplace whistleblowers in Poland do not arise from one legal act which would define the concept of a 'whistleblower' and regulate the material scope of whistleblowing, giving right to legal protection. The state guarantees protection to whistleblowers on the basis of various (global, regional and domestic) dispersed acts. Some of them concern only certain areas of economy or public policy.

Poland is bound by international conventions concerning measures against corruption which also regulate the protection of whistleblowers, ${ }^{6}$ such as conventions of the Council of Europe adopted in 1999, namely the Civil Law Convention on Corruption $^{7}$ and the Criminal Law Convention on Corruption, ${ }^{8}$ the OECD Convention on Combating Bribery of Foreign Public Officials in International Business Transactions of 1999 (Anti-Bribery Convention) ${ }^{9}$ and the United Nations Convention against Corruption of 2003. ${ }^{10}$ Polish criminal legislation concerning corruption is extensive. It does not contain measures for the protection of whistleblowers. ${ }^{11}$ However, it grants impunity for bribe-givers who denounce the crime of bribery to the competent investigative organ and inform it about all the important circumstances of the case, before the competent organ learned of it (Article 296a $\$ 1$ of the Polish Criminal Code). ${ }^{12}$

It is also worth mentioning that Poland is a party to the ILO Convention No. 176 concerning Safety and Health in Mines, 1995 which, inter alia, establishes not only the right but even a duty of employees to report dangers concerning health and security at their workplaces, ${ }^{13}$ as well as the ILO Chemicals Convention No. 170, which obliges workers to inform their supervisor immediately about the danger resulting from the use of chemicals. ${ }^{14}$ On the other hand, Poland has not ratified the ILO Convention Termination of Employment Convention, 1982 (No. 158) which, in its Article 5(c),

6 See A. Pietruszka, Ochrona sygnalistów (whistleblowers) w kontekście wolności wypowiedzi (Protection of whistleblowers in the context of freedom of expression), Ruch Prawniczy, Ekonomiczny i Socjologiczny 1/2020, p. 116.

7 Ratified by Poland on 11 September 2002, entry into force: 1 November 2003. It is worth mentioning that Article 9 of the Civil Law Convention on Corruption refers directly to employment relationships.

8 Ratified by Poland on 11 December 2002, entry into force: 1 April 2003.

9 Ratified by Poland in 2000.

10 Ratified by Poland in 2006.

11 Compare Phase 3 Report on Implementing the OECD Anti-bribery Convention in Poland, June 2013, p. 42, https://www.oecd.org/daf/anti-bribery/Polandphase3reportEN.pdf, accessed 01/09/2021.

12 See M. Pazdan, M. Zachariasiewicz, The Effects of Corruption in International Commercial Contracts, [in:] B. Lewaszkiewicz-Petrykowska (ed.), Rapports polonais, XIX Congrès international de droit comparé, Vienne, 20-26 VII 2014, Lodz University Press, Lodz 2014, p. 111.

13 See H. Szewczyk, Whistleblowing. Zgłaszanie nieprawidtowości..., op. cit., p. 49.

14 Ibidem. 
guarantees that filing of a complaint or participation in proceedings against an employer involving alleged violation of laws or regulations or recourse to competent administrative authorities shall not constitute valid reasons for termination of an employment contract. Likewise, Poland has not ratified the ILO Violence and Harassment Convention No. 190, which imposes the obligation on Member States to take appropriate measures to guarantee protection against retaliations to whistleblowers disclosing acts of violence and harassment at the workplace (Article 10).

As regards the protection of whistleblowers, it is important to mention Article 10 (Freedom of expression) of the European Convention on Human Rights (ECHR) ratified by Poland. According to the case law of the European Court of Human Rights (ECoHR), Article 10 (Freedom of expression) of the ECHR is applicable to the workplace. ${ }^{15}$

Under the ECHR, freedom of expression and information is not absolute. The state may interfere with that freedom in certain circumstances (irrespective of the medium through which opinions, information and ideas are expressed). Article 10 $\$ 2 \mathrm{ECHR}$ provides that, to be permissible, any restriction on freedom of expression must pursue one of the aims recognized as legitimate: national security, territorial integrity or public safety, protection of health or morals, prevention of disorder or crime, protection of the reputation or rights of others, prevention of the disclosure of information received in confidence or maintenance of the authority and impartiality of the judiciary. ${ }^{16}$

On 30 April 2014, the Committee of Ministers of the Council of Europe addressed the Recommendation on the protection of whistleblowers, CM/Rec (2014) 7, to Member States. This recommendation defines the 'whistleblower' as "any person who reports or discloses information on a threat or harm to the public interest in the context of their work-based relationship, whether it be in the public or private sector."

Article 54(1) of the Constitution of the Republic of Poland guarantees to everyone the freedom to express opinions and to acquire and to disseminate information as one of personal freedoms and rights. Within the scope of the employment relationship this right may constitute a legal basis allowing employees to express justified critical opinions about the employer. In cases of public whistleblowing, the exercise of the above-mentioned right may collide with the constitutional right to legal protection of a person's good reputation (Article 47 of the Constitution) or with human dignity which, in the light of Article 30 of the Constitution, shall constitute a source of freedoms and rights of persons and citizens. It shall be inviolable. The respect and protection thereof shall be the obligation of public authorities. ${ }^{17}$

15 See also M. Górski in this monograph.

16 Freedom of expression in Europe, Case-law concerning Article 10 of the European Convention on Human Rights, Human Rights files, No. 18, Council of Europe Publishing, 2007, p. 7.

17 Compare D. Skupień, Whistleblowing in Poland According to Legislation and Case Law, [in:] G. Thüsing, G. Forst (eds.), Whistleblowing - A Comparative Study, Springer, Cham 2016 p. 223 and, by the same author, The legal protection of whistleblowers in Poland, [in:] 
In the light of Article 31(2) of the Constitution, everyone shall respect the freedoms and rights of others. Possible restrictions to the freedom of expression may result only from Article 31(3) of the Constitution, which states that any limitation upon the exercise of constitutional freedoms and rights may be imposed only by statute, and only when necessary in a democratic state for the protection of its security or public order, or to protect the natural environment, health or public morals, or the freedoms and rights of other persons. Such limitations shall not violate the essence of freedoms and rights.

As a member of the European Union, Poland implemented Directive (EU) 2016/943 of the European Parliament and of the Council of 8 June 2016 on the protection of undisclosed know-how and business information (trade secrets) against their unlawful acquisition, use and disclosure. ${ }^{18}$ In the light of Article 5 of the above-mentioned Directive, the alleged acquisition, use or disclosure of a trade secret is not sanctioned where it takes place in order to exercise the right to freedom of expression and information as set out in the Charter of Fundamental Rights of the EU, including respect for the freedom and pluralism of the media, for revealing misconduct, wrongdoing or illegal activity, provided that the respondent acted for the purpose of protecting the general public interest, for the purpose of protecting a legitimate interest recognized by Union or national law or in case of disclosure by workers to their representatives as part of the legitimate exercise by those representatives of their functions in accordance with Union or national law, provided that such disclosure was necessary for that exercise. Article 5 of this Directive was implemented in Poland by the means of the Act of 16 April 1993 on combatting unfair competition (ustawa o zwalczaniu nieuczciwej konkurencji).

In the public sector, Article 63 of the Constitution may apply to whistleblowers. According to this provision, everyone shall have the right to submit petitions, requests and complaints in the public interest, in his/her own interest or in the interest of another person - with his/her consent-to public authorities, as well as to organizations and social institutions in connection with the performance of their prescribed duties within the field of public administration. The procedures for considering complaints and proposals are specified by the Code of Administrative Procedure (Articles 227-259). Complaints are lodged to public or local administration bodies and may concern, inter alia, acts of negligence or improper fulfilment of tasks of administration bodies or of their workers or breaches of rule of law (praworzadność). Requests may aim at improving the organization, strengthening the rule of law, making work more effective, preventing abuse, protecting property or a better fulfilment of societal needs.

According to Article $225 \$ 1$ of the Code of Administrative Procedure, a person lodging a complaint or a request or delivering press material assimilated to

B. Lewaszkiewicz-Petrykowska (ed.) Rapports polonais, XIX Congrès international de droit comparé, Vienne, 20-26 VII 2014,, Lodz University Press, Lodz 2014, p. 259.

18 OJ L 157, 15.6.2016, pp. 1-18. 
a complaint or request in its content may not be exposed to any harm or accusation, if he/she acted within the limits of law. The procedure of considering complaints and requests is set up in the Regulation of the Council of Ministers of 8 January 2002 on the organization of the receipt and processing of complaints and requests. ${ }^{19}$ According to this regulation, proceeding with an anonymous complaint or request is excluded.

Special protection is granted to members of local government assemblies. They cannot be dismissed for reasons related to their political activities. ${ }^{20}$

There are also legal acts which concern public sector with respect to preventing and fighting corruption. In this context, we should draw attention to the Communication from the Commission of 28 May 2003 on a Comprehensive EU Policy against Corruption ${ }^{21}$, whereby revealing corruption acts can only be achieved by the effective protection of whistleblowers against victimisation and retaliation (loss of job, personal threats etc.) and witness protection instruments as suggested in the Millennium Strategy on the prevention and control of organised crime.

In the public sector, references to whistleblowing may also be found in codes of ethics. As it concerns civil service, Order No. 70 of the Prime Minister of 6 October 2011 concerning guidelines on the respect of principles of civil service and ethical principles in the corpus of civil service ${ }^{22}$ regrettably does not concern whistleblowing. However, there are some other examples to mention. Certain codes of deontology (police, prosecutors) contain an obligation to 'react', not to 'tolerate' or not to neglect breaches of ethical principles by colleagues. ${ }^{23}$ Certain codes of ethics for local government employees established by local authorities in Poland introduce a legal obligation to denounce waste, fraud of public funds, abuse of power or corruption to appropriate institutions. ${ }^{24}$

19 Ordinance of the Council of Ministers of 8 January 2002 regarding the organisation of the acceptance and processing of complaints and requests, Dz. U. 2002.5.46.

20 See Article 25(2) of the Act on municipal self-government (ustawa o samorzqdzie gminnym), Article 22(2) of the Act on district self-government (ustawa o samorzqdzie powiatowym), Article $27(2)$ of the Act on voivodship self-government (ustawa o samorzqdzie wojewódzkim).

$21 \operatorname{COM}(2003) 317(01)$.

22 Zarządzenie nr 70 Prezesa Rady Ministrów z 6 października 2011 r. w sprawie wytycznych w zakresie przestrzegania zasad służby cywilnej oraz zasad etyki w korpusie służby cywilnej, Polish Monitor No. 93, item 953.

23 Cf. $\S 6$ of the Code of Professional Ethics of Prosecutors (Zbiór Zasad Etyki Zawodowej Prokuratorów, Załącznik do uchwaty Krajowej Rady Prokuratorów Przy Prokuratorze Generalnym z dnia 12 grudnia 2017 r.), https://pk.gov.pl/prokuratura/krajowa-rada-prokuratorow/zbior-zasad-etyki-zawodowej-prokuratorow/zbior-zasad-etyki-zawodowej-prokuratorow/, accessed 01/09/2021, or $\S 24$ of the Principles of Professional Ethics of a Police Officer (Zatącznik do zarządzenia nr 805 Komendanta Głównego Policji z dnia 31 grudnia 2003 r.), https://isp.policja. pl/isp/prawa-czlowieka-w-poli/akty-prawne-i-dokumenty/9072,Zasady-etyki-zawodowej-policjanta.html, accessed 01/09/2021.

24 Compare $\S 7(3)$ of the Code of Ethics of the employees of the Marshall's Office of Lodz, https:// bip.lodzkie.pl/urzad-marszalkowski/kodeks-etyki, accessed 01/09/2021. 
Both in the public and private sector the protection against retaliations may be based on the general provisions of the Labour Code concerning protection against dismissal, deterioration of work conditions or discrimination.

\section{Sectoral provisions}

Polish legislation covers provisions concerning whistleblowing in different sectors. The following examples can be cited here: the Act of 27 May 2004 on Investment Funds and Alternative Investment Fund Management, the Act of 29 July 2005 on Capital Market Supervision, the Act of 5 August 2015 on Macroprudential Supervision of the Financial System and Crisis Management in the Financial System, Geological and Mining Act or Aviation Act. Mechanisms for whistleblowing provided for on the basis of these legal acts were adopted to implement EU legislation. ${ }^{25}$

The legal basis for receiving and processing disclosures of money laundering and financing terrorism is established in Article 80 of the Act of 1 March 2018 on Counteracting Money Laundering and Terrorism Financing ${ }^{26}$. Competence to receive information about real and potential infringements of legal provisions concerning money laundering or terrorism financing is vested in the institution of the General Inspector for Financial Information (Generalny Inspektor Informacji Finansowej). The framework for the aforementioned proceedings was provided for in the Regulation of Minister of Finance of 16 May 2018 concerning the Receipt of Notifications of Infringements of Provisions on Counteracting Money Laundering and Terrorism Financing. ${ }^{27}$

According to the above-cited Regulation, whistleblowers include both current and former workers of the institution concerned as well as persons who carried activities for this institution on the basis other than an employment relationship. The disclosure does not affect the obligation of confidentiality.

The General Inspector is obliged to guarantee protection of personal data of persons disclosing infringements and also of persons who are accused of infringements of provisions relating to money laundering or terrorism financing. Data should be gathered in a separate data file. In particular, written and electronic documents concerning disclosures should be kept in a way that guarantees personal data protection.

25 Seeł. Bolesta, In Search of a Model..., op. cit., pp. 108-113, A. Krasuń, Sygnalista w prawie lotniczym (Whistleblower in the Aviation Act), [in:] B. Baran, M. Ożóg (eds.), Ochrona sygnalistów..., op. cit., pp. 173-183.

26 Ustawa z dnia 1 marca 2018 r. o przeciwdziałaniu praniu pieniędzy oraz finansowaniu terroryzmu, Dz. U. 2021, items 1132, 1163, 1535.

27 Rozporządzenie Ministra Finansów z dnia 16 maja 2018 r. w sprawie odbierania zgłoszeń naruszeń przepisów z zakresu przeciwdziałania praniu pieniędzy oraz finansowaniu terroryzmu, Dz. U. 2018, item 959. 
Disclosures may be introduced in a traditional correspondence format or electronically. In either case, contact address should be indicated by a whistleblower. Means of communication should be organized in a way that guarantees confidentiality and protection from access by unauthorized persons. The General Inspector indicates employees of the organizational unit to support the Inspector in the fulfilment of his/her tasks and who are to receive and process disclosures, especially with regard to follow-up measures. Access to documents related to disclosures is given exclusively to assigned workers. The content of disclosures is transmitted to assigned employees while ensuring confidentiality of personal data of the whistleblower and of the alleged perpetrator. The General Inspector may use the contact address to request additional information from the whistleblower. Information about the possible follow-up measures should be given to the contact address no longer than within 30 working days of the receipt of the disclosure.

\section{Legislative proposals concerning whistleblower protection}

Citizens' initiatives to develop a single legal act on whistleblowers first came from the Batory Foundation (2012) and then from the coalition of Forum Związków Zawodowych (the Trade Union Forum), Instytut Spraw Publicznych (the Institute of Public Affairs), the Helsinki Foundation for Human Rights and the Stefan Batory Foundation. ${ }^{28}$ The governmental proposal to regulate the legal status of whistleblowing in criminal proceedings was prepared in 2018 by the Ministry of Justice within an act with larger material scope, namely the transparency of public life (ustawa o jawności życia publicznego). ${ }^{29}$ The work on this latter proposal was stopped in the same year. Chapter 9, Articles 61-65 of the above-mentioned proposal regulated the requirements and procedure to grant the status of a whistleblower in criminal proceedings. Such status could be granted on the basis of the above-mentioned proposal only to persons denunciating certain criminal acts such as corruption (corruption in sports), malpractices on the pharmaceutical market, organized crime and certain other criminal acts related to commercial activities. The status could be granted by the public prosecutor to whom the irregularities were to be reported. During the period for which the status of whistleblowing was granted, and during one year after the discontinuance of proceedings or termination by a final judgment of criminal proceedings instituted against the perpetrator of a crime, the whistleblower was

28 The proposal is available in the Polish language on the following website: https://www.sygnalista.pl/projekt-ustawy/, accessed 01/09/2021.

29 Ustawa o jawności życia publicznego, Proposal of 8 January 2018, https://www.rpo.gov.pl/ sites/default/files/ustawa-o-jawnosci-zycia-publicznego-projekt-z\%208-stycznia-2018.pdf, accessed 01/09/2021. 
to be protected against the dismissal or deterioration of work conditions and, in case of a self-employed whistleblower, against the dissolution of the contract concluded with such a person or against the deterioration of contractual conditions. However, this prolonged protection did not apply in case of the acquittal of the accused person and also in several specific situations where criminal proceedings were discontinued. This legislative effort to regulate the status of a whistleblower could be acknowledged for the fact that it concerned not only persons employed under an employment contract but also self-employed persons. However, justified criticisms concerned the dependence of the whistleblower status on the decision of the public prosecutor, who could give the consent to the dismissal of the worker or the dissolution of a contract in case of a justified request of the employer/party to the contract. ${ }^{30}$ Provisions concerning the protection of whistleblowers were also inserted in the Draft Act on the Liability of Collective Entities for Criminal Acts of 2019. ${ }^{31}$

Nowadays, by 17 December 2021, Poland is obliged to implement Directive (EU) 2019/1937 of the European Parliament and of the Council of 23 October 2019 (with the exception of internal procedures). In the context of the implementation obligation imposed on Poland complex proposals have been formulated in legal scholarship. ${ }^{32}$

\section{Personal and material scope of whistleblowing}

At present, measures of protection against retaliation are mainly granted to employees in the strict meaning of this term, namely according to the definition provided in Article 2 of the Labour Code, i.e. natural persons employed on the basis of the employment contract, appointment, election, nomination or an employment contract in a cooperative. In case of workers employed under civil law contracts or self-employed persons, the level of protection is very weak. The available remedies consist only in claiming the compensation for damages resulted from the breach of a contract according to civil law provisions and contractual clauses. On the other hand, in accordance with the principle of freedom of contract, the parties may not conclude a consecutive contract after the expiry of the previous one. As regards temporary workers, there are no means of protecting such workers when

30 For a critical voice about this proposal, see T. Kocurek, Działalność sygnalistów..., op. cit., p. 261, H. Szewczyk, Whistleblowing. Zgłaszanie nieprawidłowości..., op. cit., pp. 131-135, Ł. Bolesta, In Search of a Model..., op. cit., p. 139.

31 Ustawa o odpowiedzialności podmiotów zbiorowych za czyny zabronione pod groźba kary, Proposal, http://orka.sejm.gov.pl/Druki8ka.nsf/Projekty/8-020-1211-2019/\$file/8-020-1211-2019. pdf, accessed 01/09/2021. For details, see Ł. Bolesta, In Search of a Model..., op. cit., p. 129.

32 See Ł. Bolesta, In Search of a Model..., op. cit., pp. 135-139 or H. Szewczyk, Whistleblowing. Zgłaszanie nieprawidtowości..., op. cit., pp. 334-337. 
they report irregularities at user undertaking. Future legislation should regulate protection against reprisals at a temporary work agency for whistleblowing at user undertaking.

In principle, protection does not extend beyond the duration of the contract except for persons covered by special protection against dismissal or a change of employment conditions to the detriment of an employee, in particular such as trade union officials, members of works councils or European Works Councils, social labour inspectors as well as employee representatives in supervisory boards. ${ }^{33}$ The period of protection extending beyond the duration of the term is defined in respective provisions of law.

The Act of 30 August 1996 on commercialization and other competencies of employees ${ }^{34}$ regulates conditions of membership and number of employee representatives in supervisory boards and management boards of commercial companies set up as a result of transformation of former state-owned companies. Employee representatives in supervisory boards of commercial companies ${ }^{35}$ are entitled to supervise and to control activities of the company according to the provisions of the Code of Commercial Companies and Partnerships. It should be noted that in a typical private business, participation of employee representatives in boards is optional and depends on the internal bylaws of the company concerned.

Board-level employee representatives are protected against dismissal with notice or against the modification of employment conditions to the detriment of an employee during the term of his/her office and during one year after the expiry thereof. ${ }^{36}$ This protection does not concern dismissals without notice ${ }^{37}$ as well dismissals within the collective redundancies procedure.

Candidates in the recruitment process are protected against discrimination under non-discrimination provisions of the Labour Code (see point 10). No protection is guaranteed for volunteers and trainees.

There is no law of general application which would define 'breaches' which may be subject of whistleblowing. However, certain sectoral provisions contain such catalogues of breaches. For example, these breaches are enumerated broadly in $₫ 5$ of the Regulation of Minister of Development and Finance of 6 March 2017 concerning

33 For details, see D. Skupień, Whistleblowing in Poland..., op. cit., pp. 225-226, Ł. Bolesta, In Search of a Model..., op. cit., pp. 104-106, H. Szewczyk, Whistleblowing. Zgłaszanie nieprawidtowości..., op. cit., pp. 256-259.

34 Ustawa z dnia 30 sierpnia 1996 r. o komercjalizacji i niektórych uprawnieniach pracowników, Dz. U. 2021, items 425, 1535.

35 For details about the scope of the board-level representation in Poland see, for instance, D. Skupień, Board-level employee participation in Polish limited-liability companies, [in:] G. Löschnigg (ed.), Arbeitnehmerbeteiligung in Unternehmensorganen im internationalen Vergleich, OGB Verlag, Wien 2011, pp. 139-161.

36 Article 15 of the Act of 30 August 1996 on commercialization and certain competencies of employees.

37 Compare Judgment of 29 March 2001 of the Supreme Court, I PKN 327/00, OSNP 2003/1/10. 
the system of risk management and internal audit system, remuneration policy and detailed method of internal capital evaluation in banks. ${ }^{38}$ The catalogue covers not only infringements of law but also infringements of procedures and standards of ethics binding at banks.

\section{Internal reporting}

Obligatory provisions on setting up internal channels for reporting irregularities or infringements are set out in the banking sector. ${ }^{39}$ We should mention Regulation (EU) No. 596/2014 of the European Parliament and of the Council of 16 April 2014 on market abuse (market abuse regulation) and repealing Directive 2003/6/EC of the European Parliament and of the Council and Commission Directives 2003/124/ EC, 2003/125/EC and 2004/72/EC. ${ }^{40}$ Article 32(1) of this Regulation imposed the obligation on Member States to ensure that competent authorities establish effective mechanisms to enable reporting or actual or potential infringements of this Regulation to competent authorities. The aforementioned Regulation of Minister of Development and Finance of 6 March $2017^{41}$ adopted on the basis of the Banking Act regulates these duties. ${ }^{42}$

The obligation to set up an internal whistleblowing system extends onto all banks. However, the reporting channels are available only to employees. Provisions of the aforementioned regulation do not explicitly exclude oral reporting.

According to $₫ 45$ point 4 of the Regulation of 2017, internal channels should be constructed in such as a way as to keep the identity of the whistleblower confidential. It is not clear to what extent anonymous disclosures are accepted. The appointment of persons operating internal channels is regulated in the banking legislation. According to $₫ 45$ point 6 of the Regulation of 2017, the management board of a bank adopts a decision to appoint a management board member responsible for the current operation of the system of internal whistleblowing to whom infringements are to be disclosed. This appointment must be confirmed by the supervisory board of the bank. In case the disclosure concerns a management member, it should be received by the supervisory board. The selection of persons who will be responsible for processing a disclosure is done on ad hoc basis, namely: after having received

38 Rozporządzenie Ministra Rozwoju i Finansów z dnia 6 marca 2017 r. w sprawie systemu zarządzania ryzykiem i systemu kontroli wewnętrznej, polityki wynagrodzeń oraz szczegółowego sposobu szacowania kapitału wewnętrznego w bankach, Dz. U. 2017.637.03.24.

39 Ł. Cichy, Whistleblowing w bankach, Komisja Nadzoru Finansowego, Warsaw 2017, https://www. knf.gov.pl/knf/pl/komponenty/img/Whistleblowing\%20w\%20bankach_58774.pdf, accessed 01/09/2021.

40 OJ L 173, 12.6.2014, p. 1-61, hereinafter: "Market Abuse Regulation".

41 Hereinafter: „Regulation of 2017”.

42 Article $9 f(1)$ and Article 128(6), ustawa z dnia 29 sierpnia 1997 - Prawo bankowe. 
a disclosure, a member of the management board or the supervisory board respectively should nominate workers, organizational units or smaller organizational divisions to be responsible for coordinating the verification of the denouncement and taking follow-up measures. In principle, the whistleblowing channel should be operated by employees of internal structures.

There is no requirement in the Regulation of 2017 that the internal channel of communication be exploited prior to the use of external reporting. While there are no legal deadlines for the response, such deadlines may be set out in internal documents establishing the whistleblowing system.

There is no legal obligation to inform the whistleblower about the follow-up of the disclosure. However, an internal document regulates the type and character of follow-up measures. An alleged 'wrongdoer' is informed at a time specified in the document establishing the internal whistleblowing system about the disclosure if the verification of the reported facts is positive while the identity of the whistleblower is protected. In case of a negative verification, the person whom the disclosure concerns is informed without any delay while the confidentiality of the whistleblower is protected.

If the verification of the report is negative, the personal data contained in the disclosure are deleted from the bank's systems. However, other information concerning the disclosure and the follow-up measures is to be kept for five years, running from the year following the year of disclosure. In case of a positive internal verification of the report, the method of protection of personal data and the duration of the protection is regulated in the internal document establishing the whistleblowing system, in accordance with personal data protection provisions.

Even without formal obligations, companies set up whistleblowing schemes which become part of systems to combat abuses and malpractices in their organisations. ${ }^{43}$ One example is the Anti-Corruption Policy of the Orlen Group ${ }^{44}$ which establishes an anonymous internal system of reporting irregularities or a whistleblower platform set up by KGHM for reporting. ${ }^{45}$ There are also numerous Polish companies or groups of companies listed on the Polish stock exchange which operate internal whistleblowing schemes, ${ }^{46}$ as recommended in the standards adopted by the Warsaw Stock Exchange to prevent corruption and protect whistleblowers. ${ }^{47}$

43 Ł. Bolesta, In Search of a Model..., op. cit., pp. 123-124.

44 Polityka antykorupcyjna (Anti-corruption policy), https://www.orlen.pl/PL/Odpowiedzialny_ Biznes/Polityka_antykorupcyjna/Strony/default.aspx, accessed 01/09/2021.

45 Linia etyki KGHM (KGHM Ethics Line) https://liniaetyki.kghm.com/pl, accessed 01/09/2021.

46 For details, see Ł. Mroczyński-Szmaj, Ochrona sygnalisty na rynku kapitałowym. Perspektywa wybranych spótek giełdowych (Whistleblower protection on the capital market. Perspective of the selected companies listed on the stock exchange), [in:] B. Baran, M. Ożóg (eds.), Ochrona sygnalistów..., op. cit., pp. 141-167.

47 See Standardy rekomendowane dla systemu zarzq̨dzania zgodnościq w zakresie przeciwdziałania korupcji oraz systemu ochrony sygnalistów w spółkach notowanych na rynkach organizowanych przez Giełdę Papierów Wartościowych w Warszawie S.A. (Recommended standards for 
There is no obligation to consult or agree the procedure of internal whistleblowing with trade unions or works councils at the workplace. In the future, introduction of such procedures should be agreed or at least consulted with the trade unions or, in their absence, with other employee representatives at the workplace.

Another question concerns the right of disclosure in the case of worker representatives who get informed about irregularities during the information and consultation procedures. Trade unionists or members of works councils are allowed to disclose such a fact. However, it may be the case that trade unionists or members of works councils reveal irregularities while having access to confidential information shared by the employer. In the latter case, the employer may pursue claims for damages related to the breach of confidentiality. In this context, attention should be drawn to the fact that trade unionists and works councils members benefit from special protection against dismissal.

\section{External reporting}

There is no single designated body responsible for receiving disclosures of breaches of law or other irregularities within external channels. Complaints may be addressed to different institutions depending on the material content of the reported breach, namely: the Ombudsman Office, Central Anti-Corruption Bureau, General Inspector of Financial Information, State Inspectorate of Labour, Inspectorate of Environmental Protection, Sanitary Inspectorate and others. There is no clear, publicly available list for potential whistleblowers indicating the bodies to receive disclosures.

There are no provisions of general application which would guarantee the protection of a whistleblower identity within external reporting. Such protection is set out in specific legal acts. ${ }^{48}$ In the realm of the controlling activities of the State Inspectorate of Labour (infringement of employment provisions or of environmental norms by the employer, etc.), the controlling inspector is not allowed to reveal to the inspected entity that the inspection was initiated by the complaint unless the complainant gives his/her written consent. ${ }^{49}$

the compliance management system with regard to anti-corruption and whistleblower protection system in companies listed on the markets organized by the Warsaw Stock Exchange S.A., https:// www.gpw.pl/pub/GPW/files/PDF/Standardy.pdf, accessed 01/09/2021.

48 See also A. Wojciechowska-Nowak, Providing an Alternative to Silence. Towards Greater Protection and Support for Whistleblowers in the EU, Country Report Poland, Transparency International 2013, p. 11, D. Skupień, Whistleblowing in Poland..., op. cit., p. 230, Ł. Bolesta, In Search of a Model..., op. cit., pp. 106-107.

49 Article 44(3) of the Act on State Inspectorate of Labour (ustawa z dnia 13 kwietnia $2007 \mathrm{r}$. o Państwowej Inspekcji Pracy, Dz. U. 2019, item 1251, consolidated text). 
Moreover, during the inspection procedure, the labour inspector may request information about the inspected entity from workers (not only employees but also workers employed under civil law contracts or self-employed persons). In this regard, the labour inspector may deliver a decision concerning the non-disclosure of the identity of a worker if there is a justified risk that such disclosure could entail damage or allegation against this worker ${ }^{50}$ (Article 23(2) of the Act on the State Inspectorate of Labour). In case of a positive decision, personal data of the worker concerned are known exclusively to the labour inspector. The report containing the worker's testimony may be revealed to the employer in a way that protects the worker's identity.

The decision of the State Inspectorate of Labour on confidentiality of personal data of a worker of the inspected entity is discretionary, and the refusal to guarantee confidentiality may not be contested by the worker concerned. The employer may contest the decision concerning the data confidentiality by lodging a complaint to the Regional Inspectorate of Labour within three days from the notification of the decision. The procedure concerning the complaint takes place without employer's attendance and behind closed doors. If the complaint is accepted, the report of the worker must be destroyed and information about the destruction of the report should be mentioned in the post-inspection report.

If the disclosed irregularities constitute criminal offences, the whistleblower may demand the status of the so-called 'incognito witness' (Article 184 of the Code of the Criminal Procedure). The status of the incognito witness may be granted by the given tribunal or during investigations by the prosecutor if there is a justified threat to life, health, freedom or substantial property of the witness or his/her close relatives (Article $184 \$ 1$ ). This means that the circumstances enabling the identity of the witness to be revealed, personal data included, are kept in secret if they are irrelevant for the judgment in the case.

The decision concerning the incognito status of a witness within criminal proceedings may be contested by the witness concerned and the accused person as well as by the prosecutor, if this is a judicial decision. The appeal against the decision is adjudicated by the court competent to judge the case. If it is revealed that there was no threat to life, health, freedom or substantial property of the witness or his/ her closest relatives, or if the witness consciously provided a false testimony, the decision on anonymity may be repealed by the tribunal in judicial proceedings or by the prosecutor during the investigation.

Anonymous disclosures are not accepted in the realm of criminal proceedings or controlling activities of the State Labour Inspectorate. Likewise, this is not allowed in the proceedings based on complaints or requests addressed to administrative authorities.

External channels may be accessed in a written or oral form. Disclosure of criminal acts may be both written and oral. In the latter case, a report is drawn up to

50 Article 23 para. 2 of the Act on the State Inspectorate of Labour. 
confirm the acceptance of the oral notification of criminal offence (Article 304a of the Code of Criminal Proceedings). Disclosures to the State Inspectorate of Labour may also take an oral or a written form, or they may be filed electronically. Complaints and requests to administrative authorities may also be lodged in a written or oral form..$^{51}$ The Central Anti-Corruption Bureau accepts phone calls from whistleblowers disclosing acts of corruption. ${ }^{52}$ Deadlines for response (feedback) to the whistleblower depend on the authority to which the disclosure is submitted.

\section{Public disclosures and the freedom of expression}

There is no legal definition of 'public disclosure'. On the basis of the case law of the Supreme Court, this notion may be defined as disclosing irregularities in public, namely through the press, social media or during public meetings or gatherings. According to Article 5(6) of Directive 2019/1937/EU, 'public disclosure' means the making of information on breaches available in the public domain.

There is no general obligation under the law stating that public denouncement must always be preceded by internal and/or external whistleblowing. However, this may be the case in certain professions. As an example, we may cite Article 52(2) of Chapter III of the Polish Code of Medical Ethics", entitled "Mutual relations between physicians," which provides that "A physician should display particular caution in formulating opinions on the professional conduct of another doctor and in particular he/she should not in any way discredit him/her publicly." According to Article 52(3) of the above-cited Code, any comments on the observed erroneous conduct of a physician should, in the first place, be shared with that physician. Further on, if such an intervention appears to be inefficient or if the erroneous conduct or the violation of ethical principles causes serious damage, the relevant body of the medical chamber must be notified. ${ }^{54}$

Similar restrictions in formulating criticisms concerning colleagues are defined in the Code of Ethics of Nurses and Midwives (point III.3). ${ }^{55}$ In the light of this

51 Compare $\S 5$ of the Regulation on the organization of receipt and proceeding with complaints and requests.

52 See the official webpage of the Central Anti-Corruption Bureau, https://cba.gov.pl/pl/kontakt/97,Kontakt.html, accessed 01.09.2021.

53 Kodeks etyki lekarskiej (Code of Medical Ethics), https://nil.org.pl/dokumenty/kodeks-etyki-lekarskiej, accessed 01/09/2021.

54 Kodeks etyki lekarskiej (Code of Medical Ethics), https://nil.org.pl/uploaded_images/1574857770_kodeks-etyki-lekarskiej.pdf, accessed 01/09/2021.

55 Kodeks etyki zawodowej pielęgniarki i położnej Rzeczypospolitej Polskiej (Code of Ethics of Nurses and Midwives of the Republic of Poland, https://nipip.pl/prawo/samorzadowe/krajowy-zjazd-pielegniarek-i-poloznych/kodeks-etyki-zawodowej-pielegniarki-i-poloznej-rzeczypospolitej-polskiej/, accessed 01/09/2021. 
provision, criticism should be formulated in an impartial way and it should be primarily shared directly with the person concerned. In case there is no reaction and if erroneous acts are repeated, the nurse/midwife should inform the relevant body of the Nurses and Midwives' Chamber.

Pursuant to Article 5 of the Act on the Press ${ }^{56}$, anyone may give information to the press in line with the principle of freedom of expression and the right to criticism. No one can suffer any harm or receive any pleas as a consequence of having passed information to the press if he or she acted within the limits of law.

On the other hand, the breach of personal interests such as good reputation or secrecy of correspondence of a person incurs civil liability for the perpetrator. ${ }^{57} \mathrm{Ar}-$ ticle 24 of the Civil Code provides for ways of redressing infringements of personal rights. According to that provision, a person facing the danger of an infringement may demand that the prospective perpetrator refrain from the wrongful activity unless it is not unlawful. Where an infringement has taken place, the person affected may, inter alia, request that the wrongdoer make a relevant statement in an appropriate form, or just claim satisfaction from him or her. If an infringement of a personal right causes financial loss, the person concerned may seek damages. According to Article 43 of the Civil Code, provisions concerning the protection of personal interests of physical persons also apply respectively to personal interests of legal persons. The breach of personal interests of legal persons involves allegations which, taken objectively, would ascribe improper conduct to them, such as mistreatment of workers (e.g. mobbing, improper customer handling, non-fulfilment of public or private obligations that may result in the loss of confidence in this person, necessary to achieve his/her goals in the course of business $\left.{ }^{58}\right)$.

In a case concerning allegations that homeopathic medicines produced by a certain company may transmit avian flu and, therefore, represent a lethal risk for patients, it was judged that the defendant infringed the good reputation of the company by publicly presenting information which was not truthful. ${ }^{59}$

In this context, in the light of the case law of the Polish civil courts, we may distinguish claims concerning infringements of Article 23 of the Civil Code filed against journalists and against other persons. This distinction was based on Article 12(1) of the Act on Press which states that a journalist should show particular diligence while gathering and using press materials, and especially check the veracity of the information received or indicate its source.

A resolution of the Supreme Court of 18 February 2005 (III CZP 53/04 OSNC 2005, No. 7-8, p. 114) clarifies the scope of assessment of legality of journalists' actions. According to the conclusion of this resolution, a journalist's actions would not be considered illegal if they were made in the public interest and the duty to

56 Dz. U. 2018, item1914, consolidated text (ustawa z dnia 26 stycznia 1984 r. Prawo prasowe).

57 Articles 23-24 of the Civil Code.

58 See judgment of the Supreme Court of 18 September 2019, IV CSK 297/18.

59 Judgment of the Supreme Court of 10 May 2007, III CSK 73/07. 
act with due diligence was fulfilled. Imposing an obligation on a journalist to prove the veracity of each statement would unjustifiably limit the freedom of the press in a democratic society. This approach was confirmed in a recent case law of the Supreme Court, ${ }^{60}$ where it was underlined that the requirement of due diligence in case of journalists is higher than elsewhere.

In case of criticisms publicly expressed by persons who are not journalists, there was a requirement to prove the truthfulness of statements in order to escape civil liability. According to the case law of the Supreme Court in civil cases, ${ }^{61}$ restrictions to the freedom of expression have to be interpreted as exceptions to the rule and must fulfil the criteria of purposefulness, legality and necessity. However, the right to the legal protection of good reputation has the same importance and merits the same protection as freedom of expression. The necessity to prove the true character of the information transmitted in a public debate in a press interview is not an excessive requirement. This approach of the Supreme Court was questioned by the ECoHR in the case of Braun v. Poland of 4 November 2014.

The case of Braun v. Poland of 4 November 2014 concerned the complaint by a film director and historian who was ordered to pay a fine and to publish an apology for having damaged the reputation of a well-known professor to whom he had referred, in a radio debate, as an informant of the secret political police during the communist era. The ECoHR did not accept the Polish courts' approach that required the applicant to prove the truthfulness of his allegations. In the light of the ECoHR case law and the circumstances of the case, it was not justified to require the applicant to meet a standard more demanding than that of due diligence only on the grounds that the domestic law had not considered him to be a journalist. The Court held that there had been a violation of Article 10 (freedom of expression) of the Convention.

We should also mention other interesting ECoHR cases against Poland concerning the breach of Article 10 ECHR (freedom of expression), which ended with positive rulings for the complainants. In the case of Wojtas-Kaleta v. Poland ${ }^{62}$ the ECoHR decided that the infringement of Article 10 by Poland took place in a situation where the journalist, who was an employee and, at the same time, a trade unionist, was reprimanded by the employer (a public television company) for having publicly criticized the employer's broadcasting policy.

The case of Frankowicz v. Poland of 16 December 2008 concerned a gynaecologist and the President of the Association for the Protection of the Rights of Patients in Poland. Disciplinary proceedings were initiated for the complainant's report on the treatment of a patient in which he was critical of another doctor, following which he was sanctioned by the Medical Court and given a reprimand. The ECoHR held that

60 Judgment of the Supreme Court of 9 February 2018, I CSK 325/17.

61 Cf. judgment of the Supreme Court of 25 February 2010, I CSK 220/09.

62 Wojtas-Kaleta v. Poland, 2009, ECoHR 20436/02 (Fourth Section, 16 July 2009). 
there had been a violation of Article 10 of the Convention, finding that the interference with the applicant's freedom of expression had not been proportionate to the legitimate aim pursued, namely protecting the reputation of others. It observed in particular that, in the applicant's case, the Polish authorities had concluded, without having attempted to verify the truthfulness of the findings in the medical opinion, that the applicant had discredited another doctor. That decision was made on the basis of the absolute prohibition of any criticism between doctors in Poland, which was set out in the Code of Medical Ethics binding at that time. The Court considered that the absolute prohibition was likely to discourage doctors from providing their patients with an objective opinion on their health and any treatment received, which could compromise the very purpose of the medical profession, namely to protect the health and life of patients ${ }^{63}$.

It should be added that on 23 April 2008 the Constitutional Court delivered a judgment (SK16/07) in which it found that Article $52 \$ 2$ of the Code of Medical Ethics was unconstitutional in so far as it prohibited the truthful public assessment of the activity of a doctor by another doctor in the public interest.

In the case of Stankiewicz and Others v. Poland of 14 October 2014, the applicants were two journalists and the publisher of the national daily newspaper where they both worked. The case concerned an article they published in that paper, in which they alleged that a high official of the Ministry of Health was involved in corrupt practices. The applicants complained that the Polish courts' decisions had violated their right to freedom of expression. The Court held that there had been a violation of Article 10 (freedom of expression) of the Convention, finding in particular that the Polish judicial authorities had not carried out a careful balancing exercise between the right to impart information and protection of the reputation or rights of others. The reasons relied on by Poland to justify the interference with the applicants' right to freedom of expression, although relevant, were not sufficient to show that that interference was necessary in a democratic society.

On the other hand, in the case of D. Kania v. Poland of 19 July 2016, the ECoHR did not find the violation of Article 10 of the Convention by Poland. This case concerned the applicant's conviction on charges of defamation after publishing an article in a national weekly, claiming that the communist secret police had created the Polish mafia and protected it throughout the 1980s. The article also claimed that government officials who became members of the police services under the post-1989 democratic system had continued to protect their former colleagues still involved in the thriving world of organised crime. The Court held that there had been no violation of Article 10 (freedom of expression) of the Convention, finding that the applicant's conviction and sentence were not disproportionate to the legitimate aim pursued, namely the protection of the reputation or rights of others. The Polish authorities could therefore reasonably find that the interference with the exercise by 
the applicant of her right to freedom of expression was necessary in a democratic society in order to protect the reputation and rights of others. ${ }^{64}$

To summarise, in case of journalists who have a social duty to provide information, a whistleblower can avoid civil liability for false criticisms if they fulfilled the duty of due diligence when gathering and presenting the information. On the other hand, Polish courts required a higher standard: that of veracity in case of persons other than journalists. This latter approach was not shared by the ECoHR and became mitigated in the recent caselaw of the Supreme Court (e.g. I NSNc 89/20). ${ }^{65}$

As regards disclosures of criminal acts which are pursued in the criminal proceedings following an act of whistleblowing, a court should not release a journalist from the obligation to protect the personal data of a person who was an author of a press material, a letter to the editor or other material as well of persons transmitting information which was later published or transferred for publication if these persons requested anonymity ${ }^{66}$. A journalist's refusal to reveal such personal data does not exempt them from criminal liability which may arise due to the publication of specific information.

\section{Case law in labour disputes concerning control of dismissals due to the public presentation of criticism about the employer}

The case law of the Supreme Court adjudicating in labour cases suggests that an employee is entitled to public criticisms about the employer ${ }^{67}$ However, certain conditions should be met for criticism to be permissible. According to the Supreme Court judgment of 18 July 2012 (I PK 44/12), critical statements about the employer and disclosure of information to the owner of the establishment about possible irregularities do not represent a serious infringement of the employee's duties even if the charges appear to be unjustified at a later date. However, the allegations should be made in good faith with the belief that the irregularities exist at the workplace. In its judgment of 25 November 2014 (I PK 98/14), the Supreme Court stated that when assessing permissibility of criticism, the court should consider whether criticism is substantive, reliable, adequate to specific factual circumstances and presented in an appropriate form. According to the Supreme Court, in that case

64 https://www.echr.coe.int/Documents/FS_Reputation_ENG.pdf, accessed 01/09/2021.

65 See more about the ECoHR caselaw M. Górski in this monograph.

66 Compare Article $180 \S 3$ of the Polish Code of Criminal Proceedings.

67 See also D. Skupień, Whistleblowing in Poland according to Legislation and Case Law, [in:] G. Thüsing, G. Forst (eds.), Whistleblowing - A Comparative Study, Springer, Cham Heidelberg New York Dordrecht London, p. 228. 
the basic feature of permissible criticism is the employee's 'good faith', i.e. if the employee has a subjective belief that criticism is based on truthful facts (while exercising due diligence in checking their veracity) and acts in the justified interest of the employer. ${ }^{68}$ Moreover, public criticism should not lead to violation of employee obligations consisting, in particular, in acting in the interests of the workplace and maintaining confidentiality of information which, if disclosed, could expose the employer to harm (duty of loyalty, respect of employer's interests as in Article 100 $\$ 1$ point 4 of the Labour Code), as well as in compliance with the internal rules of social co-existence (Article $100 \$ 2$ point 6 of the Labour Code).

According to the Supreme Court judgment of 7 December 2006 (I PK 123/06), permissible and constructive criticism made by the manager of an establishment who criticises actions taken by the owner of an organizational entity does not violate the obligation of protecting the employer's interests but, on the contrary, it is a proof of such care. The employer's retaliatory actions aimed at discrediting the employee and detrimental to the employee's personal rights (Article 111 of the Labour Code), undertaken in response to permissible and constructive criticism made by the manager with regard to unfavourable decisions adopted by the founding body or owner, may be classified as a serious breach of essential obligations towards the employee, entitling the employee to terminate the employment contract without notice due to the employer's fault (Article $55 \$ 1^{1}$ of the Labour Code) ${ }^{69}$

\section{Financial incentives}

The EU Market Abuse Regulation allows Member States to provide for financial incentives to persons who offer relevant information about potential infringements of this Regulation to be granted in accordance with national law where such persons do not have other pre-existing legal or contractual duties to report such information, and provided that the information is new, and that it results in the imposition of an administrative or criminal sanction, or the taking of another administrative measure, for an infringement of this Regulation (Article 32(4)). However, Polish Regulation of 2017 does not provide for financial incentives. In this context, we may also draw attention to the institution of a person cooperating with the police who is not a police officer. ${ }^{70}$ This person may be remunerated. On the other hand, such police informers cannot be assimilated to whistleblowers.

68 See also judgement of the Supreme Court of 10 May 2018, II PK 74/17 and I PK 48/13.

69 S. W. Ciupa, Niedozwolona krytyka pracodawcy ze strony pracownika jako przyczyna wypowiedzenia umowy o pracę (Illegal worker criticism of the employer by the employer as the reason for dismissal with notice), Monitor Prawniczy (Legal Monitor) 2002, No. 20, p. 925.

70 Article 22 of the Act on Police (ustawa z dnia 6 kwietnia 1990 r. o policji), Dz. U. 2020, items $360,956,1610,2112,2320$ with later amendments. 


\section{Obligation to blow the whistle}

The obligation for workers to disclose irregularities existing at the workplace may be derived from Article $100 \$ 2$ point 4 of the Labour Code, which states that employees are obliged to take care of the interests of their workplace (the obligation which is not identical with the good or interests of the employer). This opinion is not universally shared in literature. ${ }^{71}$

The analysis of whistleblowing in the context of duty or faculty only should take into consideration variety of infringements which may be disclosed. Certainly, any employee has the duty to denounce criminal acts he/she became aware of at the workplace. They are also obliged to report about the accidents at work or the risks to human life or health (Art. 211 point 6 of the Labour Code). As regards other infringements, the assessment of the obligatory character of disclosure should include such elements as the position and the range of responsibilities of the employee concerned.

The qualified level of duty to care for common values is assumed for civil servants, local government employees and employees of state administration bodies. The obligation to protect interests of the State is a primordial duty of employees of state administration bodies. ${ }^{72}$ Likewise, civil servants are obliged, inter alia, to serve the interests of the Polish State (Article 50 of the Act on civil service). Local government workers are obliged to take care of public interests, and their service to the public precedes the care for the interests of a public entity (Article 18(1) of the Act on local government workers). This obligation is confirmed in the words of oath taken by the employee.

The general duty of citizens to inform the Public Prosecutor's Office or the police applies to anyone who received information about a criminal offence prosecutable by public prosecution (Article $304 \$ 1$ of the Code of Criminal Procedure). This duty is not legally enforceable, except for the duty to report the most serious crimes against peace, humanity and state security etc.

The legally enforceable obligation to notify the police or the Public Prosecutor's Office and to undertake all necessary actions in order not to allow the traces and proofs of the infringement to be destroyed lies with the State and local administration institutions which receive information about the commitment of criminal infraction prosecuted by a public prosecutor in relation to their activities (Article $304 \S 2$ of the Code of the Criminal Procedure). However, this reporting obligation does not apply to any employees of the institution but only to persons who have managerial or controlling functions. The non-fulfilment of this duty may result in penal

71 See A. M. Świątkowski, Sygnalizacja (whistleblowing) a prawo pracy (Whistleblowing and the labour law), Przegląd Sądowy (Judicial Review) 2015/5/6-25.

72 Article 17 of Act on state administration bodies, ustawa o pracownikach urzędów państwowych, Dz. U. 1982 No. 31, item 214. 
responsibility provided for civil servants in Article $231 \$ 1$ of the Criminal Code (the sanction of maximum three years of imprisonment). ${ }^{73}$

Trade unions are entitled to inspect the employers' compliance with labour law provisions as well as health and safety regulations and to require that competent public bodies eliminate the irregularities disclosed (Article 23 of the Polish Trade Unions' Act of 1991).

We should also mention social labour inspectors whose competencies cover the inspection of compliance with health and safety regulations, environmental legislation as well as employer's compliance with labour law provisions.

\section{Protection against retaliation}

The Polish legislation of general application does not stipulate a catalogue of possible retaliatory measures against whistleblowers. However, such a general catalogue is inserted into the Regulation of 2017 relating to the banking sector. According to $\$ 45(4)$ point 2 of that Regulation, when denouncing infringements through the internal whistleblowing system, the whistleblower is protected against reprisals, discrimination and other forms of unfair treatment. No provisions regulate the protection of supporters of whistleblowers (e.g. witnesses), their family members unless it concerns witnesses or supporters in discrimination cases on grounds of whistleblowing.

According to Article $55 \$ 1$ of the Labour Code, an employee may request a change of job if holding a medical certificate confirming a detrimental effect of the current job for the employee's health. If the employer refuses to transfer the employee to another job that would be appropriate with regard to his/her health and qualifications, the employee may terminate the contract without notice. Such option may be applied in case of the deterioration of a psychic conditions of a worker provoked by a conflict with colleagues or a supervisor.

The judicial control of valid grounds for dismissal with notice is possible only in case of an open-ended contract of employment. In case of fixed-term contracts as well as probation contracts, the labour court may only control the legality of notice.

If the employment contract is still binding, the employee may request that the labour court renders the notice ineffective. If a fixed-term contract or a probation contract has expired, the dismissed employee may only demand damages in case of illegality of the dismissal with notice. In case of open-ended contracts, the employee may also demand reinstatement in work if she/he was illegally or unfairly dismissed

73 See also M. Derlacz-Wawrowska, Whistleblowing a ochrona informacji poufnych pracodawcy (Whistleblowing and the protection of the confidential information of the employer), [in:] G. Uścińska (ed.), Prawo pracy. Refleksje i poszukiwania (Labour Law. Reflections and Explorations), Studia i Monografie IPiSS, Warsaw 2013, pp. 397-398. 
with notice (Article $45 \$ 1$ and 2 of the Labour Code). However, also in case of open-ended contracts, the labour court only awards damages if the reinstatement in work is impossible or aimless (the request for reinstatement is always possible for persons at the pre-retirement age and benefitting from special protection related to maternity/paternity, unless it is not the case of liquidation or insolvency of the enterprise).

If a whistleblower is unfairly dismissed without notice (disciplinary dismissal) for a serious breach of employee's duties, he or she may request either reinstatement in work or payment of damages, independently of the type of employment contract held. However, an employee is not entitled to reinstatement if a fixed term contract has expired or there is only a short period left until expiry. In that case, an employee may only request the payment of damages. Trade union officials and works council members benefit from special protection against dismissal. ${ }^{74}$

In case of open-ended contracts, compensation for unfair dismissal with notice amounts to the remuneration for the period of two weeks to three months, however it may not be lower than the remuneration for the whole period of notice. Moreover, in case of reinstatement in work, the worker is entitled to remuneration for the time of joblessness, but for no more than two months, and for no more than one month in case of a three-month period. The limitation of damages does not apply to persons benefitting from special protection related to maternity/paternity and workers at the pre-retirement age.

In case of illegal dismissal with notice applied to workers employed under a probation contract, damages are paid in the amount covering the period until the date when the contract was supposed to expire.

Damages to an illegally dismissed employee who was employed under a fixedterm contract amount to their remuneration covering the period until the date when the contract was supposed to expire but no more than three months' worth of remuneration.

In case of unfair disciplinary dismissal, the employee may get damages amounting to his/her remuneration for the period of notice. In case of unfair disciplinary dismissal of an employee employed under a fixed-term contract, the damages amount to the remuneration for the period left until the expiry date of the fixed-term contract but no more than for the notice period.

Individuals who are not employees and whose contract has been terminated or whose conditions of work were deteriorated as a result of whistleblowing may only claim compensation for the damages resulted from the breach of contract under the civil law provisions and the contractual clauses.

No protective measures are provided for in the case of trainees or job candidates who have made a disclosure.

74 Compare respectively Article 32 of the Trade Union Act and Article 17 of the Act on informing and consulting with employees. 


\section{Whistleblowing and anti-discrimination measures}

Whistleblowing is not included expressly in the catalogue of forbidden criteria of discrimination according to the Labour Code. According to Article 183a $\$ 1$ of the Labour Code, employees should be treated equally with regard to conclusion and termination of employment contracts, the terms of employment, promotion and access to vocational training aimed at upgrading their professional qualifications, in particular independently of gender, age, disability, race, religion, nationality, political opinion, trade union membership, ethnic origin, belief, sexual orientation, employment for a fixed term or for an indefinite period of time, part-time or full-time employment. Doubts persist if this catalogue is an open or a semi-open set of criteria. According to the case law of the Supreme Court, discrimination is defined as a situation where an employee is treated less favourably when this is not justified by objective grounds for reasons such as personal attributes which are relevant from the social point of view or for the reason of being employed for a fixed term or for an indefinite period of time, or being employed part-time or full-time (Supreme Court case II PK 82/12). According to this judgment, a reversal of the burden of proof in discrimination cases would apply to alleged discrimination on grounds of the above-mentioned criteria (Article 183b $₫ 1$ of the Labour Code) or other personal characteristics or features. Recently, the prevailing interpretation has been that Article 183a $\$ 1$ of the Labour Code sets out an open catalogue of criteria.

The Act of 3 December 2010 on the implementation of certain provisions of the European Union concerning equal treatment ${ }^{75}$ applies to conditions where professional or economic activity is undertaken or carried out. This latter Act is complementary to anti-discrimination provisions of the Labour Code as it regulates legal measures and claims pursued by self-employed persons and persons employed under civil law contracts. This legal act defines a closed catalogue of grounds of discrimination which refer to criteria announced in directives 2006/54/EC, 2000/78/ EC and 2000/45/EC, namely gender, racial and ethnic origin, nationality, religion, confession or beliefs, disability, age or sexual orientation.

Moreover, sanctioning the discriminative refusal to employ a candidate for a vacancy with a fine in amount of no less than PLN 3,000 concerns only discrimination on particular grounds referred to in the above-cited EU anti-discrimination directives, namely gender, age, disability, racial origin, religion, nationality, political beliefs, ethnic origin, confession or sexual orientation. ${ }^{76}$

If labour courts follow the interpretation that the catalogue of discrimination criteria referred to in Article $18^{3 a} \S 1$ of the Labour Code is an open one, whistleblowers

75 Ustawa z dnia 3 grudnia 2010 r. o wdrożeniu niektórych przepisów Unii Europejskiej w zakresie równego traktowania (Dz. U. 2020 r. item 2156).

76 See Article 23 of the Act on the promotion of employment and labour market institutions (ustawa z dnia 20 kwietnia 2004 r. o promocji zatrudnienia i instytucjach rynku pracy, Dz. U. 2020, items 1409, 2023, 2369, 2400). 
would be obliged only to plausibly demonstrate the facts of discrimination and it is upon the employer to prove that unequal treatment was due to objective reasons. The burden of proof is not reversed in case of whistleblowers who sue their employers for unequal treatment if they are employed under a civil law contract. As indicated above, the Act on the implementation of certain provisions of the European Union concerning equal treatment contains a closed catalogue of criteria.

According to the Labour Code, the legal time limits for employees to pursue claims is three years from the date the claim becomes enforceable (Article $291 \S 1$ of the Labour Code).

\section{Whistleblower and the criminal liability}

A whistleblower who diffuses false information on irregularities at the workplace may be held responsible for the defamation, as per Article $212 \S 1$ of the Criminal Code. The offence of defamation consists in accusing someone of conduct or characteristics that may degrade him/her in public opinion or expose him/her to loss of confidence necessary for a given position, occupation or type of activity. The proceedings are pursued upon the request of the defamed person. In case of conviction for the offence of the defamation, the court may award damages for the victim or payment towards any social cause indicated by the victim. Penalties include a fine or limitation of liberty (Article $212 \S 1$ of the Criminal Code). The penalty is more severe when the offense of defamation takes place through the media (Article $212 \S$ 2 of the Criminal Code) and it includes a fine, limitation of liberty but also imprisonment for up to one year. It is also more difficult for the whistleblower to liberate herself/himself from the charge of defamation if the accusation is done through the media. In case of non-public defamation, it is sufficient to prove that the accusation was true. In case of defamation through the media, there are two conditions to be met: firstly, the critical opinion must be true and secondly, it must serve a socially justified interest (Article $213 \$ 2$ point 2 of the Criminal Code).

With regard to the alleged offence of the defamation, only truthful allegations (in pursuit of socially justified interest, in case of the defamation through the media) exonerate the whistleblower from criminal liability. In consequence, the Supreme Court (judgment of 4 September 2003, IV KKN 502/00) indicated that the condition of socially justified interest is not fulfilled if the accusation is not confirmed (uncertain) even though it would appear later to be true. Moreover, the Supreme Court has judged that the defamation done while knowing that the information delivered and the alleged characteristics of another person are not truthful, never serves a socially justified aim.

In this context, we should draw attention to the Council of Europe Resolution 1577 (2007), entitled "Towards decriminalisation of defamation." According to this Resolution, statements or allegations which are made in the public interest, even if 
they prove to be inaccurate, should not be punishable provided that they were made without knowledge of their inaccuracy, without intention to cause harm, and their truthfulness was checked with proper diligence.

In this Resolution, the Council of Europe urged countries whose laws still provide for prison sentences-although imprisonment might not be actually adjudicatedto abolish them without delay so as not to give any excuse, however unjustified, to countries which continue to impose such penalties, thus provoking a corrosion of fundamental freedoms. The Council of Europe recommended that only incitement to violence, hate speech and promotion of negationism be punishable by imprisonment. ${ }^{77}$

When analysing criminal responsibility, one has to bear in mind that if information about criminal offence is reported to the prosecution bodies while knowing that no such offence was committed, this constitutes a criminal offence in itself and is penalized with a fine, limitation of liberty or imprisonment of up to two years (Article 238 of the Criminal Code).

On the other hand, we may also draw attention to the type of criminal offence described in Article $266 \S 1$ of the Criminal Code, namely the disclosure of information in breach of legal provisions or against the obligation imposed on the disclosing person, where such information was obtained in relation to a function, job or public, social, commercial or scientific activity. Such an act is penalised with a fine, limitation of liberty or imprisonment of up to two years. A qualified form of this offence is provided for in Article $266 \$ 2$ of the Criminal Code, which refers to disclosure of information to a person who is not entitled to receive it and where information was identified as 'reserved' or 'confidential' and was received in connection with official duties. If the disclosure of such information may cause prejudice to legally protected interests, this is sanctioned with the penalty of imprisonment of up to three years. This offence is prosecuted at request of a victim.

\section{Whistleblowing and the protection of trade secrets (professional secrets)}

According to Article 11(1) of the Act of 16 April 1993 on combating unfair competition ${ }^{78}$, disclosure, use or acquisition of information constituting a secret of an enterprise constitutes an act of unfair competition. Breach of confidentiality may lead to civil liability for damages caused to the enterprise as well as to criminal liability.

The secret of an enterprise is understood as technical, technological, organizational information about the enterprise or other information of economic value which, as a whole or in a particular combination and collection of their elements, is

77 See also ECoHR in case Matalas against Greece, complaint No. 1864/18, 25 March 2021.

78 Ustawa z dnia 16 kwietnia 1993 r. o zwalczaniu nieuczciwej konkurencji, Dz. U. 2020, item 1913. 
not commonly known to persons usually dealing with this type of information or is not easily accessible to such persons, provided that the person authorised to use or dispose of the information has undertaken, with due diligence, to keep it confidential (Article 11(2) of the Act on combating unfair competition).

Article 11(8) of the Act of 16 April 1993 on combating unfair competition states that the disclosure, use or acquisition of information that constitutes a trade secret is not an act of unfair competition when it was aimed to protect a legitimate interest protected by law as part of exercising one's freedom of expression or to disclose irregularities, misconduct, actions in breach of law to protect public interest, or when disclosure of a trade secret to employees' representatives in the performance of their functions under the law was necessary for proper performance of those functions.

However, only entrepreneurs may be sued in a civil action for acts of unfair competition. According to the jurisprudence of Polish courts ${ }^{79}$, workers may also be sued in exceptional cases if there is a causal link between the act of unfair competition and the commercial activity carried out by the entrepreneur.

In any case, in the light of Article $100 \$ 2$ and 4 of the Labour Code, an employee is obliged to observe the secrecy of information which, if revealed, could be prejudicial to the employer and also to respect professional secrets defined in respective legal acts. The breach of the aforementioned duty may lead to a disciplinary dismissal of the employee concerned.

In this context, we should also mention that various other legal acts binding in Poland provide for the obligation of confidentiality in certain professions (medical doctors, barristers, legal counsels, tax consultants, etc.).

\section{Sanctions for interrupting or preventing whistleblowing}

No sanctions exist that would directly refer to acts consisting in interrupting or preventing an act of whistleblowing. However, sanctions provided for certain types of criminal acts may be applied, for example for the criminal offence of a punishable threat (Article 190 of the Criminal Code), punished with imprisonment of up to two years. Qualified types of offences refer to the use of violence or punishable threat in order to influence a witness, judicial expert, interpreter, accuser or accused, or in relation to violating their bodily integrity (penalised with imprisonment of three months to five years, as per Article 245 of the Criminal Code). The sanction of at least one year and up to 10 years of imprisonment is applicable to public functionaries or other persons acting on command of a public functionary in order to guarantee that the public functionary can receive, for instance, a certain testimony

79 Cf. judgment of the Appellate Court in Cracow of 23 September 2017, I ACa 411/2017. 
or declaration, and also to individuals who use violence, punishable threat or other forms of physical or psychological forms of abuse against another person.

There are also specific provisions establishing penal sanctions for acts of inhibiting or scotching activities undertaken by specific inspection bodies, such as the sanitary inspectorate or the environmental protection inspectorate.

Such acts are respectively punishable with arrest, or alternatively with limitation of liberty or a fine, and in case of environmental inspections they are punishable with a fine between PLN 10,000 and 100,000 (cf. Article 38 of the Act on Sanitary State Inspection ${ }^{80}$ and Article 31c of the Act on Environmental Inspection ${ }^{81}$ ).

\section{Conclusions}

According to the common opinion, the present Polish legislation does not guarantee an appropriate level of protection for whistleblowers. The means of protection are set out in various legal acts. There exists an unquestionable necessity to adopt a legal act dedicated to whistleblower protection and such an act is currently being developed by the Polish government. This act should implement the EU Whistleblower Protection Directive and go beyond it.

The main drawback of the present regulations concerning the protection of whistleblowers against dismissal or discriminative measures under the Labour Code in Poland is that the Labour Code provisions do not protect workers employed under civil law contracts. Thus, this is contrary to the recommendation of the Council of Europe ${ }^{82}$ and to Directive 2019/1937/EU, whereby the legal protection of whistleblowing should cover all individuals working in either the public or the private sector, irrespective of the nature of their working relationship and whether they are paid or not.

The material scope of whistleblowing should cover breaches not only of the EU law enumerated in Article 2(1) of the Directive 1937/2019 but also breaches of law or regulations in general. The legislator should also include acts such as mobbing, violence at work, harassment or breaches of health and safety provisions. The catalogue of prohibited retaliatory measures should be defined broadly. In case of labour disputes concerning dismissal or discrimination of a whistleblower, the burden of proof should be reversed.

Internal channels for whistleblowing should be set up in all companies employing at least fifty workers. The structure of such channels should guarantee confidentiality of whistleblowers' personal data and precise timetables for the internal

80 Dz. U. 2020, items 322, 374, 567 and 1337.

81 Dz. U. 2020, items 995 and 1339.

82 Recommendation $C M / \operatorname{Rec}(2014) 7$ adopted by the Committee of Ministers of the Council of Europe on 30 April 2014 and explanatory memorandum, Protection of whistleblowers, point 3. 
investigative procedures and responses to whistleblowers. Trade unions should have the right to negotiate internal regulations concerning whistleblowing schemes with the employer.

A dedicated whistleblower central office should be established with the aim to guarantee measures of support for whistleblowers, to provide them with information about the appropriate external channels in specific sectors and possibly also transmit the reports to the competent external bodies. Sanctions concerning the disclosure of the whistleblower's personal data should be dissuasive and should cover fines related to the turnover of the company as well as imprisonment for natural persons who reveal the identity of the whistleblower. Certainly, employers have to be protected by appropriate instruments of civil and criminal law as well as a procedure against false disclosures. The freedom of expression should not be misused to harm the reputation of natural and legal persons. However, the penalty of imprisonment imposed for alleged defamation by the whistleblower seems too severe and, as such, should be eliminated. Finally, apart from setting up new procedures and institutions, a positive image of whistleblowers needs to be created in society: this may be crucial for postcommunist countries, helping to overcome psychological barriers related to disclosures of irregularities.

\section{Abstract}

The chapter analyses the current legal situation of whistleblowers in work-related context in Poland. Protection of whistleblowers is not regulated by a single comprehensive legal act but may be granted on the basis of different pieces of legislation as well as according to the case law of the Supreme Court, which established the concept of 'permissible criticism' expressed by a worker. The level of whistleblower protection is by no means satisfactory, especially as regards atypical workers. The author assesses the shortcomings of the current legal situation and presents proposals for improvement in the light of the EU Whistleblower Protection Directive and international conventions ratified by Poland.

\section{Bibliography}

Bolesta Ł., In Search of a Model for the Legal Protection of a Whistleblower in the Workplace in Poland, Peter Lang, Berlin 2020.

Cichy Ł., Whistleblowing w bankach (Whistleblowing in Banks), Komisja Nadzoru Finansowego, Warsaw 2017, https://www.knf.gov.pl/knf/pl/komponenty/img/Whistleblowing\%20 w\%20bankach_58774.pdf, accessed 01/09/2021.

Ciupa S. W., Niedozwolona krytyka pracodawcy ze strony pracownika jako przyczyna wypowiedzenia umowy o prace (Illegal worker criticism of the employer by the employee as the reason for dismissal with notice), Monitor Prawniczy (Legal Monitor) 2002, No. 20. 
Derlacz-Wawrowska M., Whistleblowing a ochrona informacji poufnych pracodawcy (Whistleblowing and the protection of the confidential information of the employer), [in:] G. Uścińska (ed.), Prawo pracy. Refleksje i poszukiwania (Labour Law. Reflections and Explorations), Studia i Monografie IPiSS, Warsaw 2013.

Kocurek T., Działalność sygnalistów jako przejaw społeczeństwa obywatelskiego w szerszym kontekście historycznoprawnym (Whistleblower activity as a manifestation of civil society in a broader historical and legal context), [in:] B. Baran, M. Ożóg (eds.), Ochrona sygnalistów. Regulacje dotyczace osób zgłaszających nieprawidłowości (Protection of whistleblowers. Rules concerning persons disclosing irregularities), Wolters Kluwer, Warsaw 2021.

Krasuń A., Sygnalista w prawie lotniczym (Whistleblower in the Aviation Act), [in:] B. Baran B., M. Ożóg (eds.), Ochrona sygnalistów Regulacje dotyczące osób zgłaszających nieprawidłowości (Protection of whistleblowers. Rules concerning persons disclosing irregularities), Wolters Kluwer, Warsaw 2021.

Mroczyński-Szmaj Ł., Ochrona sygnalisty na rynku kapitałowym. Perspektywa wybranych spółek giełdowych (Whistleblower protection on the capital market. Perspective of the selected companies listed on the stock exchange), [in:] B. Baran, M. Ożóg (eds.), Ochrona sygnalistów Regulacje dotyczace osób zgłaszajacych nieprawidłowości (Protection of whistleblowers. Rules concerning persons disclosing irregularities), Wolters Kluwer, Warsaw 2021.

Ożóg M., Sygnalizacja naruszeń prawa a zasada praworządności $w$ dziejach prawa polskiego - zarys problematyki (Disclosures of breaches of law and the principle of rule of law in the history of Polish law - the outline of problems), [in:] B. Baran, M. Ożóg (eds.), Ochrona sygnalistów. Regulacje dotyczące osób zgłaszających nieprawidłowości (Protection of whistleblowers. Rules concerning persons disclosing irregularities), Wolters Kluwer, Warsaw 2021.

Pazdan M., Zachariasiewicz M., The Effects of Corruption in International Commercial Contracts, [in:] B. Lewaszkiewicz-Petrykowska (ed.), Rapports polonais, XIX Congrès international de droit comparé, Vienne, 20-26 VII 2014, , Lodz University Press, Lodz 2014.

Pietruszka A., Ochrona sygnalistów (whistleblowers) w kontekście wolności wypowiedzi (Protection of whistleblowers in the context of freedom of expression), Ruch Prawniczy, Ekonomiczny i Socjologiczny $1 / 2020$.

Savage A., Whistleblowers for change. The social and economic costs and benefits of leaking and whistleblowing, Open Society Foundations 2018.

Skupień D., Whistleblowing in Poland according to Legislation and Case Law, [in:] G. Thüsing, G. Forst (eds.), Whistleblowing - A Comparative Study, Springer, Cham Heidelberg New York Dordrecht London 2016.

Skupień D., The legal protection of whistleblowers in Poland, [in:] B. Lewaszkiewicz-Petrykowska B. (ed.), Rapports polonais, XIX Congrès international de droit comparé, Vienne, 20-26 VII 2014, Lodz University Press, Lodz 2014.

Skupień D., Board-level employee participation in Polish limited-liability companies, [in:] G. Löschnigg (ed.), Arbeitnehmerbeteiligung in Unternehmensorganen im internationalen Vergleich, OGB Verlag, Vienna 2011.

Szewczyk H., Whistleblowing. Zgłaszanie nieprawidłowości w stosunkach zatrudnienia (Whistleblowing. Disclosing irregularities in employment relations), Scholar, Warsaw 2020.

Świątkowski A. M., Sygnalizacja (whistleblowing) a prawo pracy (Whistleblowing and the labour law), Przegląd Sądowy (Judicial Review) 2015/5/6-25.

Wojciechowska-Nowak A., Providing an Alternative to Silence. Towards Greater Protection and Support for Whistleblowers in the EU, Country Report Poland, Transparency International 2013. 